\title{
Maternal Embryonic Leucine Zipper Kinase
}

National Cancer Institute

\section{Source}

National Cancer Institute. Maternal Embryonic Leucine Zipper Kinase. NCI Thesaurus.

Code $C 134700$.

Maternal embryonic leucine zipper kinase (651 aa, $\sim 75 \mathrm{kDa}$ ) is encoded by the human MELK gene. This protein plays a role in the mediation of protein phosphorylation that regulates cell cycle, cell death and cell proliferation. 